\title{
Oleic Acid and Diketopiperazines Produced by Marine Bacteria Reduce the Load of the Pathogen Vibrio parahaemolyticus in Argopecten purpuratus
}

\section{Yanett Leyton ${ }^{1,2 *}$ and Carlos Riquelme ${ }^{1}$}

${ }^{1}$ Centro de Bioinnovación, Laboratorio de Ecología Microbiana. Facultad de Recursos del Mar. Universidad de Antofagasta, Chile

${ }^{2}$ Programa de doctorado en Ciencias Aplicadas, Mención Sistemas Marinos Costeros, Facultad de Recursos del Mar, Universidad de Antofagasta, Chile

\begin{abstract}
The aquaculture industry must often deal in its cultures with bacterial contamination by Vibrio parahaemolyticus, which causes gastroenteritis in humans when they eat contaminated organisms. Until recently these pathogens were treated with antibiotics which are now forbidden because of their negative effects on humans and on the ecosystem. In the last few years there have been attempts to solve this problem by searching for active metabolites from antagonist bacteria. The objetive of this work was to evaluate the decrease of the load of the pathogen $V$. parahaemolyticus in Argopecten purpuratus scallops by the addition of oleic acid and diketopiperazines isolated from marine bacteria known for having an antibacterial effect against the pathogen, and with commercially available products similar to the molecular structures isolated from the bacteria. The decrease of the pathogen load was determined by the most probable number method from the absence in the samples of the gene tdh that codes for thermostable direct hemolysin (TDH), the main virulence factor in this species. The $A$. purpuratus bivalves treated with the oleic acid and diketopiperazines isolated from the bacteria showed preliminarily that they cause a reduction of the bacterial load of the $V$. parahaemolyticus pathogen. The same trend was seen when the scallops were treated with commercial oleic acid and diketopiperazines. Based on the inhibiting activity seen with the commercial products we suggest the possibility of experimenting with these products against $V$. parahaemolyticus or other pathogens in different commercially important organisms, mainly in depuration systems that require a short time (12 to 24 hours) to reduce the concentration of human pathogens like $\mathrm{V}$. parahaemolyticus.
\end{abstract}

Keywords: Antibacterial; Oleic acid; Diketopiperazines; Vibrio parahaemolyticus; Argopecten purpuratus

\section{Introduction}

The marine ecosystem is a potential source of microorganisms that produce antibacterial compounds [1]. The search for marine microorganisms as producers of therapeutic agents began in the 20th century [2]. At present almost $10 \%$ of the 1.000 .000 known biologically active metabolites are of microbial origin [3]. The first research wrongly attributed the active metabolites to marine eukaryotes, but later the activity of the microorganisms that live associated with them was recognized [4].

In the aquaculture industry pathogenic bacteria have become multiresistant to traditional antibiotics used as antifouling agents, antibacterials, antiparasitics, anesthetics, and disinfectants. The amounts of antibiotics used by these industries are not always available to the public [5], but it is known that their use has caused significant damage to marine ecosystems, resulting in an increase of clinical complications in cases that could previously have been treated successfully, longer hospitalization, and greater costs to society [6]. The possibility of implementing the use of bacterial active metabolites in the culture systems of commercial organisms through the direct injection of their extracts or live strains is an alterantive that is gaining importance due to the interest in optimizing the production of commercial organisms with environmentally fiendly alternatives. Growth, reduction of malformations, resistance to disease, and microbial equilibrium can be achieved through the modulation of the intestinal microbiota, increase of favorable bacteria, production of inhibiting compounds to compete with the pathogen, inhibiting the expression of virulence genes and improving immune response [7].

Bacteria of the genera Vibrio and Bacillus are known for their probiotic properties [8] detected 300 pathogen inhibiting bacteria of the family Vibrionaceae, and those with the highest activity were identified as $V$. coralliilyticus, Vibrio neptunios and Photobacterium halotolerans, from which two antibiotics identified as andrimid (from V. coralliilyticus) and holomycin (from P. halotolerans) were isolated . Mujeeb et al. [9] found inhibiting activity in bacteria of the genus Bacillus isolated from cultures of the shrimp Macrobrachium rosenbergii against pathogenic Aeromonas hydrophila, Vibrio parahaemolyticus, Vibrio vulnificus, and Escherichia coli bacteria. Similarly, Avella et al. [10] suggested beneficial effects on the growth of Sparus aurata fish by adding a mixture of bacteria of the genus Bacillus (B. lincheniformis, $B$. pumilus and B. subtilis). Somnath et al. [11] showed resistance to disease and survival in cultures of larvae of Penaeus monodon by the addition of probiotics (Bacillus MCCB 101, Pseudomonas MCCB 102/103 and Arthrobacter MCCB 104) that act against the pathogen Vibrio harvey, showing that Bacillus and Arthrobacter operate as probiotics through immunostimulating digestive enzymes. More recent studies by Qinghui et al. [12] show that diets supplemented with Bacillus subtilis in a dose of 1x107 CFU/g improve growth, feeding efficiency ratio, immune response and resistance to disease of juvenile Larimichthys crocea. However, the evaluation of the effect of the bioactive compounds from marine bacteria on the reduction of the pathogenic bacterial load in mollusks is scarce.

*Corresponding author: Yanett Leyton, Bioinnovation Center, Microbial Ecology Laboratory, Faculty of Marine Resources, Universidad de Antofagasta, Antofagasta Chile; Tel: +56-55-637532; Fax: +56-55-637804; E-mail: yleyton@uantof.cl

Received January 09, 2013; Accepted March 20, 2013; Published March 30, 2013

Citation: Leyton Y, Riquelme C (2013) Oleic Acid and Diketopiperazines Produced by Marine Bacteria Reduce the Load of the Pathogen Vibrio parahaemolyticus in Argopecten purpuratus. J Aquac Res Development 4: 179 doi:10.4172/2155 9546.1000179

Copyright: $\odot 2013$ Leyton Y, et al. This is an open-access article distributed under the terms of the Creative Commons Attribution License, which permits unrestricted use, distribution, and reproduction in any medium, provided the original author and source are credited. 
Preliminary studies in our laboratory have identified metabolites active against the pathogenic bacteria $V$. parahaemolyticus from two marine bacteria: oleic acid from Vibrio sp. [1] and diketopiperazines from Bacillus pumilus [13]. Based on these data the present study has the purpose of verifying the anti- $V$. parahaemolyticus activity of oleic acid and diketopiperazines in the bivalve Argopecten purpuratus infected with the pathogen.

\section{Materials and Methods}

\section{Source of the strains and product extraction}

The inhibiting bacteria Bacillus pumilus (C32) and Vibrio sp. (C33), and the pathogenic Vibrio parahaemolyticus (strain PM48.5 who possesses the $t d h$ gene) were obtained from the strain collection of the Laboratorio de Ecología Microbiana of the Universidad de Antofagasta. The three bacteria were kept in collections in Tryptone Soya Agar (TSA Oxoid Ltd., Basingstoke, Hampshire, England) culture medium supplemented with $2 \% \mathrm{NaCl}$ (TSA Oxoid Co.) under axenic conditions at $20 \pm 1^{\circ} \mathrm{C}$ and frozen in crioperls. Vibrio sp. was cultivated in minimum medium M9 [14] and B. pumilus in M9 medium modified (casamino acid $1 \mathrm{~g} \mathrm{l}-1 ; \mathrm{Na}_{2} \mathrm{HPO}_{4} 1 \mathrm{~g} \mathrm{l}^{-1} ; \mathrm{KH}_{2} \mathrm{PO}_{4} 2 \mathrm{~g} \mathrm{l}^{-1} ; \mathrm{NH}_{4} \mathrm{Cl}_{1} \mathrm{~g} \mathrm{l}^{-1} ; \mathrm{NaCl} 4 \mathrm{~g} \mathrm{l}^{-1}$; DW $960 \mathrm{ml}, 10 \mathrm{ml} \mathrm{MgSO}_{4}\left(24 \mathrm{~g} \mathrm{l}^{-1}\right) ; 10 \mathrm{ml} \mathrm{CaCl}_{2}\left(1.5 \mathrm{~g} \mathrm{l}^{-1}\right) ; 1 \mathrm{ml}$ vitamin $\mathrm{B} 1\left(10 \mathrm{~g} \mathrm{l}^{-1}\right) ; 100 \mathrm{ml}$ glucose $\left.\left(200 \mathrm{~g} \mathrm{l}^{-1}\right) ; \mathrm{pH} 4\right)$ at an initial concentration of $1 \times 10^{7}$ cells $\mathrm{mL}^{-1}$ at $20^{\circ} \mathrm{C}$ with constant stirring. Extraction of the antibacterial products was made at 96 hours of cultivation by adding $150 \mathrm{~mL}$ of ethyl acetate (Winkler ET-0790, Mexico) per liter of culture (bacteria+supernatant). The organic phase was recovered and allowed to stand for 20 min over sodium sulfate, (Merck, Germany), filtered through filter paper, concentrated to dryness in a rotavapor at $45^{\circ} \mathrm{C}$, and placed for 24 hours in a lyophilizer to remove the moisture. The extract was stored at $-20^{\circ} \mathrm{C}$ until its later use.

\section{Evaluation of the best dose inhibiting bacterial product}

The experiment was performed to determine the approximate dose of active product that provides the best inhibition of pathogenic bacteria. $V$. parahaemolyticus $(V p)$ was inoculated at an initial concentration of $1 \times 10^{5}$ cells $\mathrm{mL}^{-1}$ in test tubes with $10 \mathrm{~mL}$ of $\mathrm{M} 9$ culture medium. Growth was measured at $4,8,12,24$ and 48 hours by taking a $1 \mathrm{~mL}$ aliquot of each treatment and reading its spectrophotometric absorbance $(600$ $\mathrm{nm})$. The concentrations used were the following: $\mathrm{Vp}+\mathrm{PC} 32(V p+1 \mathrm{mg}$ mL-1 of product from $\mathrm{C} 32) ; \mathrm{Vp}+\mathrm{C} 33\left(\mathrm{Vp}+1 \mathrm{mg} \mathrm{mL}^{-1}\right.$ of product from C33), using Vp+M (Vp+methanol (Merck 1.07018.2511, Darmstadt, Germany) solvent with which the product was diluted) as control; $\mathrm{Vp}+\mathrm{C}\left(\mathrm{Vp}+1 \mathrm{mg} \mathrm{mL} \mathrm{m}^{-1}\right.$ of commercial chloramphenicol antibiotic (Sigma-Aldrich CO378-25G, St. Louis, USA), an inhibitor of $V p$ ). During the experiment the samples were kept at $20^{\circ} \mathrm{C}$ and sampling was made in triplicate.

\section{Effect of the bacterial product on infected scallops}

Previously acclimated $A$. purpuratus scallops were infected with $V$. parahaemolyticus $(\mathrm{Vp})$ at a concentration of $1 \times 10^{5}$ cells $\mathrm{mL}^{-1}$ during 18 hours. Then, in covered plastic containers with 1 liter of seawater and 3 scallops (treated with UV radiation and filtered to $1 \mu \mathrm{m}$ ) to discard stress factors, the antibacterial product was inoculated at a concentration of $1 \mathrm{mg} \mathrm{mL}^{-1}$. The treatments used were: CT ( $V p$ without antibacterial product); $\mathrm{P}-\mathrm{C} 32\left(V p+1 \mathrm{mg} \mathrm{mL}^{-1}\right.$ product from $\left.\mathrm{C} 32\right)$, and $\mathrm{P}-\mathrm{C} 33(V p+1$ $\mathrm{mg} \mathrm{mL} \mathrm{L}^{-1}$ product from C33). 24 hours after treating the infected scallops with the antibacterial products each organism was placed in a separate container with $100 \mathrm{~mL}$ of marine saline solution and they were blended with a hand blender. The presence of $V$. parahaemolyticus in the tissues of the mollusk was expressed by the most probable number
(MPN) as described in the Bacteriological Analytical Manual of the Food and Drug Administration [15]. For that purpose each mixtrure was diluted into 3 series in triplicate in alkaline peptone water (APW) enriched culture medium (peptone $10 \mathrm{~g}, \mathrm{NaCl} 10 \mathrm{~g}$, distilled water 1000 $\mathrm{mL}, \mathrm{pH}$ 8.4). The samples were incubated in a thermostatic bath at $37^{\circ} \mathrm{C}$ overnight, then $1 \mathrm{~mL}$ of each sample was boiled at $100^{\circ} \mathrm{C}$ for $15 \mathrm{~min}$ and centrifuged at $14.000 \mathrm{rpm}$ for $10 \mathrm{~min}$ at $4^{\circ} \mathrm{C}$. Finally, the presence of $t d h$ (fwd 5'-GTA AAG GTC TCT GAC TTT TGG AC-3', rev 5'-TGGAAT AGA ACC TTC ATC TTC ACC-3') y th (fwd 5'-AAA GCG GAT TAT GCA GAA GCA CTG-3', rev 5'-GCT ACT TTC TAG CAT TTT CTC TGC-3') genes [16] of $V$. parahaemolyticus that indicate pathogenicity was determined qualitatively in agarose gels by the polymerase chain reaction $(\mathrm{PCR})$.

\section{Effect of oleic acid and diketopiperazine in infected scallops}

In plastic containers with $50 \mathrm{~L}$ of seawater (previously treated with UV radiation and filtered to $1 \mu \mathrm{m}) 22$ scallops infected with $V$. parahaemolyticus $(V p)$ under the same conditions mentioned in the previous step were added. The experiment was conducted in a closed loop system of water. When the commercial antibacterial product 1 $\mathrm{mg} \mathrm{mL}^{-1}$ of oleic acid (OA) (Sigma-Aldrich 364525-1L, St Louis, USA) and diketopiperazines (DKP) (Sigma-Aldrich 362557-5G, St Louis, USA) was added, the water level was reduced to $30 \mathrm{~L}$, that will not affect the scallops, allowing the product to act for 40 min with manual stirring every $10 \mathrm{~min}$, then the water level was restored to $50 \mathrm{~L}$. The treatments were: CT (scallop uninfected and without antibacterial product); Vp (scallop with Vp without antibacterial product); C (scallop with $V p+$ chloramphenicol $1 \mathrm{mg} \mathrm{mL}^{-1}$ ); DKP (scallop with $V p$ +diketopiperazine); OA (scallop with $V p$ +oleic acid). After 24 hours of the treatment of the infected scallops with the commercial antibacterial products, samples were taken in triplicate from each treatment and they were processed for the MPN method in the same way as in the previous step.

\section{Statistical Analysis}

The data were analyzed by one-way ANOVA [17] after determining fulfillment of the variance homogeneity assumptions (Bartlett's test), the normal distribution of the data (Kolmogorov-Smirnov test), the normality of the residuals (Anderson-Darling test), the independence and linearity of the model using the MINITAB 14 statistical software.

\section{Results}

\section{Inhibition of the pathogen at different product concentrations}

In our work the antibacterial product from strains C32 and C33 showed inhibition of the pathogen $V$. parahaemolyticus during the first 12 hours of culture, with significant differences with respect to the controls (cultivation of $V$. parahaemolyticus without the addition of products). At 24 and 48 hours an increase was seen in the cultures with the active products but lower than the controls (Figure 1).

\section{Effect of the bacterial product on infected scallops}

The MPN analysis of the infected $A$. purpuratus scallops treated for 24 hours with the antibacterial products showed a decrease of the pathogen load of bacteria C32 with 5.587 (MPN/100 g of scallop) and C33 with 2.634 (MPN/100 g of scallop) with respect to the control, 10.943 (MPN/100 g of scallop) (Figure 2). 


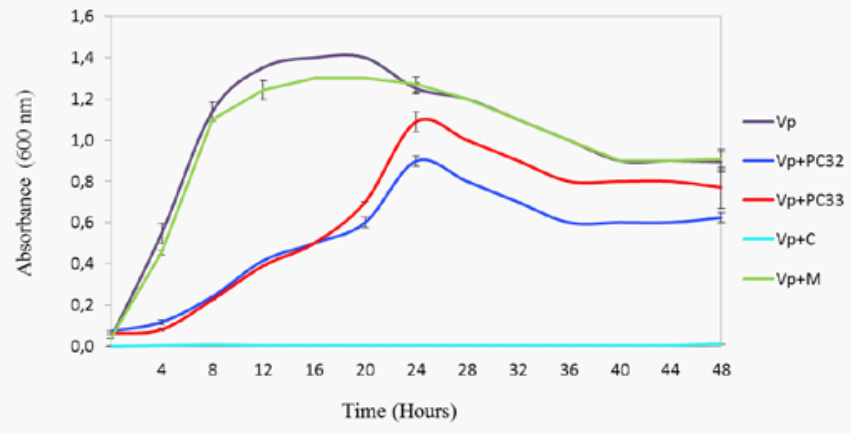

Figure 1: Effects of antibacterial products on the growth of the pathogen V. parahaemolyticus. Vp (Vp without antibacterial product). Vp+PC32 $(V p+1$ $\mathrm{mg} \mathrm{mL}^{-1}$ of product from Bacillus pumilus C32); $\mathrm{Vp}+\mathbf{C} 33\left(\mathrm{Vp}+1 \mathrm{mg} \mathrm{mL}^{-1}\right.$ of product from Vibrio $\mathrm{sp}$. C33); and $\mathbf{V p}+\mathbf{M}(\mathrm{V}+$ +methanol, solvent in which the product was diluted) as control; $\mathbf{V p}+\mathbf{C}\left(\mathrm{Vp}+1 \mathrm{mg} \mathrm{mL}^{-1}\right.$ of chloramphenicol) commercial antibiotic inhibitor of $V p$.

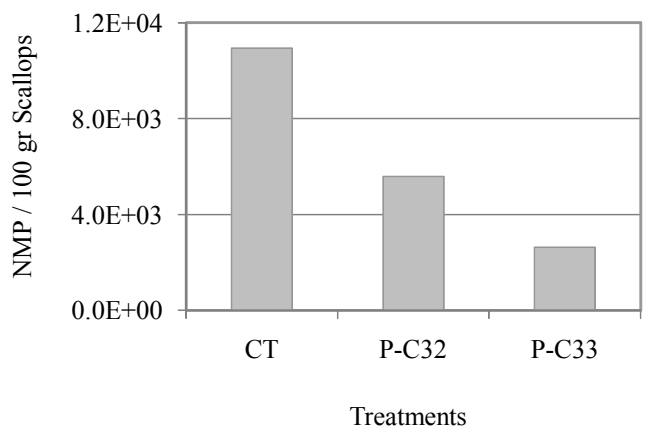

Figure 2: Evaluation of the inhibiting activity of the products isolated from the antagonist bacteria against the pathogen $\mathrm{V}$. parahaemolyticus $(\mathrm{Vp})$ shown by the decrease of the $t d h$ gene indicator of the presence of the pathogen in the tissues of scallops. MPN (most probable number of pathogenic bacteria per $100 \mathrm{~g}$ of scallops); CT (Vp without antibacterial product); P-C32 (Vp+product from Bacillus pumilus C32), and P-C33 (Vp+product from Vibrio sp. C33).

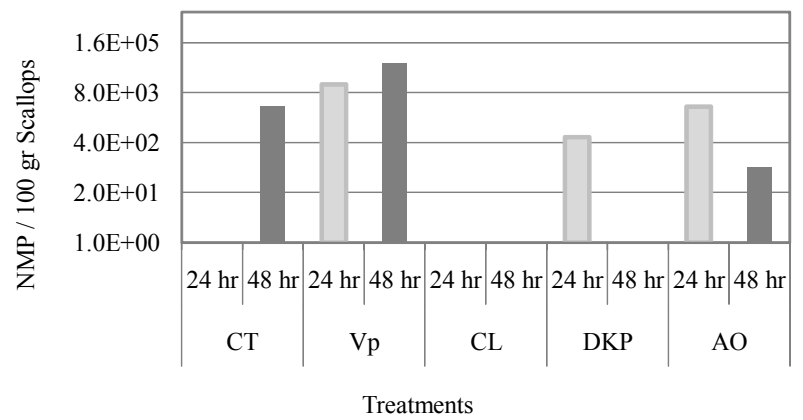

Figure 3: Evaluation of the inhibiting activity of the commercial products against the pathogen $V$. parahaemolyticus $(V p)$ shown by the decrease of the $t d h$ gene indicator of the presence of the pathogen in the tissues of the scallop. MPN (most probable number of pathogenic bacteria per $100 \mathrm{~g}$ of scallops); CT (scallop uninfected and without antibacterial product); Vp (scallop with $V p$ without antibacterial product); $\mathrm{CL}$ (scallop with $V p+$ chloramphenicol); DKP (scallop with $V p$ +diketopiperazine); OA (scallop with $V p+o l e i c$ acid); $\mathrm{hr}$ (hours)

\section{Effect of the commercial product on infected scallops}

In the CT treatment (scallops uninfected and untreated with OA and DKP) the presence of the thl gene was seen at 48 hours of culture, indicating that the scallops were bearers of the pathogen $V$. parahaemolyticus. The Vp treatment (scallops infected for 18 hours with the pathogen) shows that the scallops were infected and that the concentration of the pathogen had increased by 48 hours of culture. The CL treatment (scallops traeated with chloramphenicol) showed its good antibiotic effect as the presence of the $t d h$ gene was not detected during the experiment, but it should be noted that $100 \%$ survival was seen in all the treatments and controls, except for the control treatment with cloramphenicol (CL), where $27 \%$ mortality was found at 24 hours and $100 \%$ mortality at 48 hours, showing the toxicity of chloramphenicol, in contrast with what was found in the treatments with the commercial OA and DKP, with which no mortality was seen in the treated scallops. The DKP treatment (scallops treated with commercial DKP) showed the best antibiotic effect against the pathogen, with a decrease from 46.736 (MPN/100 g of scallops) with the Vp treatment to 0 (MPN/100 $\mathrm{g}$ of scallops) with the DKP treatment at 48 hours of culture. The OA treatment also showed a decrease from 46.736 (MPN/100 $\mathrm{g}$ of scallops) with the Vp treatment to 91 (MPN/100 g of scallops) at 48 hours of culture (Figure 3 ).

\section{Discussion}

There is evidence of the beneficial effect of probiotic bacteria in culture systems. For example, García de la banda et al. [18] evaluated strains of the genus Shewanella in juveniles of Solea senegalensis (sole), finding that these bacteria affect the intestinal microbiota providing protection against the pathogen Photobacterium damselae subsp. piscicida. García de la banda et al. [19] tested the nutritional effects of Shewanella putrefaciens bacteria on the cultivation of $S$. senegalensis juveniles against the pathogen $P$. damselae subsp. piscicida, finding increased growth rates of the fish when the probiotic was inoculated fresh at a concentration of $1 \times 109$ cells/g. Al-Dohail et al. [20] mention that the probiotic Lactobacillus acidophilus is a good candidate for use as biocontrol against pathogenic bacteria such as Staphylococcus xylosus, Aeromonas hydrophila and Streptococcus agalactiae in cultures of Claries gariepinus fish juveniles. But once we have information on the probiotic effect of various bacteria it is necessary to identify the active metabolites to evaluate the feasibility of using them in culture systems.

The active products of bacteria Bacillus pumilus and Vibrio sp. used in this study were identified previously by Leyton et al. [1], but one of the problems found by the authors was due to the small amount of extracted product per liter of culture. Since the identified products are known and the objective of our work was to show the effectiveness of oleic acid and diketopiperazines in larger volumes, the work was done with commercially available compounds. Oleic acid is easy to obtain at a convenient price, but it was not possible to find the same diketopiperazine structures isolated by the authors, so the work was done with the most structurally similar DKPs available, whose cost was far higher than that of OA. The MPN results showed that the commercial DKP (Sigma-Aldrich 362557-5G) and OA (Sigma-Aldrich 364525-1L) reduced the load of the pathogen $V$. parahaemolyticus in A. purpuratus $48 \mathrm{~h}$ after treating the scallops with these products, with a reduction in the scallop's tissues of the tdh gene which codes for thermostable direct hemolysin (TDH), the main virulence factor in this species, and based on the preliminary results of the reduction of the pathogen in scallops treated with the products obtained from the bacteria, the reduction of the pathogen in the tissues of the scallop can be attributed to the OA and DKP molecules.

We report for the first time the benefits of using diketopiperazines and oleic acid to reduce the load of the pathogen V. parahaemolyticus 
Citation: Leyton Y, Riquelme C (2013) Oleic Acid and Diketopiperazines Produced by Marine Bacteria Reduce the Load of the Pathogen Vibrio parahaemolyticus in Argopecten purpuratus. J Aquac Res Development 4: 179 doi:10.4172/2155-9546.1000179

Page 4 of 5

in adult individuals of Argopecten purpuratus, without affecting the viability of the bivalves. These results represent a contribution to the discussion by Bhatnagar and Kim [21], who state that marine microorganisms have not received the attention they deserve, and there is a very limited vision of the bioactive capacities and potential in the literature available to date. DKPs and their derivatives have previously been described as an interesting source of secondary metabolites with both antifungal and antibiotic bioactive properties [22]. For example, Fdhila et al. [23] found DKP activity against Vibrio anguillarum isolated from bacteria associated with cultures of Pecten maximus. The various acknowledged biological actions of DKPs make them more interesting for research on their clinical [24] and aquacultural potential. On the other hand, the antibacterial activity of OA is commonly attributed to the fact that its action mechanism is the inhibition of the synthesis of fatty acids [25]. For example, its inhibiting activity against the pathogenic oral bacteria Streptococcus mutans has been identified [26]. However, the possibility is open to do new research that will allow us to optimize the production of the metabolites generated by the bacteria for their use in culture systems. In this way the preparation of products on a larger scale for their later marketing would be facilitated. Merrifield et al. [7] state that current studies on the application of probiotics and prebiotics in aquaculture are quite varied, making it difficult to plan a strategy for their efficient application at a commercial level and suggest that future studies should be centered on providing practical applications on an industrial scale. Finally, in the CT treatment (scallops uninfected and untreated with OA and DKP) the presence of the $t d h$ gene, indicating that the scallops were bearers of the pathogen $V$. parahaemolyticus. In this respect it should be mentioned that the presence of $V$. parahaemolitycus was reported in the Bay of Antofagasta during outbreaks in 1997 and 1998 [27].

\section{Conclusions}

Based on the inhibiting activity seen with the commercial products, we propose the possibility of testing these products against $V$. parahaemolyticus or other pathogens in different commercially important organisms, mainly in depuration systems that require short times (12 to 24 hours) to reduce the concentration of human pathogens like $V$. parahaemolyticus.

\section{Acknowledgements}

The financial support of the Beca de Doctorado Proyecto MECESUP (ANT0711), the Beca Financiamiento de Tesis Doctoral, Conicyt, and FONDEF project MRO7I1006 and project FONDEF AQ1210016 is gratefully acknowledged. The authors thank Fernando Valenzuela and Mauricio Cáceres for their diving and fishing of the scallops, Marcela Martínez and Rodrigo Varas for their support carrying out the experiment.

\section{References}

1. Leyton Y, Borquez J, Darias J, Cueto M, Díaz-Marrero A, et al., (2011) Oleic Acid Produced by a Marine Vibrio spp. Acts as an Anti-Vibrio parahaemolyticus Agent. Marine Drugs 9: 2155-2163.

2. Monaghan RL, Tkacz JS (1990) Bioactive microbial products: Focus upon mechanism of action. Annual Review of Microbiology 44: 271-301.

3. Penesyan A, Kjelleberg S, Egan S (2010) Development of Novel Drugs from Marine Surface Associated Microorganisms. Mar Drugs 8: 438-459.

4. Sudek S, Lopanik NB, Waggoner LE, Hildebrand M, Anderson C, et al., (2007) Identification of the putative bryostatin polyketide synthase gene cluster from "Candidatus Endobugula sertula", the uncultivated microbial symbiont of the marine bryozoan Bugula neritina. J Nat Prod 70: 67-74.

5. Burridge L, Weis JS, Cabello F, Pizarro J, Bostick K (2010) Chemical use in salmon aquaculture: A review of current practices and possible environmental effects. Aquaculture 306: 7-23.

6. Maragakis LL, Perencevich EN, Cosgrove SE. (2008) Clinical and economic burden of antimicrobial resistance. Expert Review of Anti-infective Therapy 6 : 751-763

7. Merrifield DL, Dimitroglou A, Foey A, Davies SD, Baker R, et al. (2010) The current status and future focus of probiotic and prebiotic applications for salmonids. Aquaculture 302: 1-18.

8. Wietz M, Manon M, Gotfredsen CH, Larsen TO, Gram L (2010) Antibacteria Compounds from Marine Vibrionaceae Isolated on a Global Expedition. Marine Drugs 8: 2946-2960.

9. Mujeeb RKM, Jesmi Y, Thomas AP, Hatha AAM (2010) Probiotic effect of Bacillus NL110 and Vibrio NE17 on the survival, growth performance and immune response of Macrobrachium rosenbergii (de Man). Aquaculture Research 41: 120-134.

10. Avella MA, Gioacchini G, Decamp O, Makridis P, Bracciatelli C, et al. (2010) Application of multi-species of Bacillus in sea bream larviculture. Aquaculture 305: 12-19.

11. Somnath S, Anas A, Subramaniam N, Priyaja P, Sreelakshmi B, et al. (2010) Penaeus monodon larvae can be protected from Vibrio harveyi infection by pre-emptive treatment of a rearing system with antagonistic or non-antagonistic bacterial probiotics. Aquaculture Research 41: 847-860.

12. Qinghui A, Xu H, Mai K, Xu W, Wang J, et al. (2011) Effects of dietary supplementation of Bacillus subtilis and fructooligosaccharide on growth performance, survival, non-specific immune response and disease resistance of juvenile large yellow croaker, Larimichthys crocea. Aquaculture 317: 155161.

13. Leyton Y, Borquez J, Darias J, Cueto M, Díaz-Marrero AR, et al. (2012) Diketopiperazines Produced by an Bacillus Species Inhibits Vibrio Parahaemolyticus. J Aquaculture Research and Development 3:144.

14. Gerhardt P, Murra RGE, Wood WA, Krieg NR (1994) Methods for General and Molecular Bacteriology; American Society for Microbiology: Washington, DC USA.

15. Kaysner CA, DePaola A (1998) Vibrio cholerae, V. parahaemlyticus, V. vulificus, and other Vibrio spp. Bacteriological Analytical Manual. 8th ed., rev A Food and Drug Administration, Washington. Chap.9.

16. Bej AK, Patterson DP, Brasher CW, Vickery MCL, Jones DD, et al. (1999) Detection of total and hemolysin-producing Vibrio parahaemolyticus in shellfish using multiplex PCR amplification of $\mathrm{tl}$, tdh and trh. J Microbiol Methods 36 215-225.

17. Zar J (1994) Biostatistical Analysis; Prentice-Hall: New York, NY, USA.

18. García de La Banda I, Lobo C, León-Rubio JM, Tapia-Paniagua SM, Balebona C, et al. (2010) Influence of two closely related probiotics on juvenile Senegalese sole (Solea senegalensis, Kaup 1858) performance and protection against Photobacterium damselae subsp. Piscicida. Aquaculture 306: 281-288.

19. García de la Banda I, Lobo C, Chabrillón M, León-Rubio JM, Arijo S, et al. (2012) Influence of dietary administration of a probiotic strain Shewanella putrefaciens on senegalese sole (Solea senegalensis, Kaup 1858) growth, body composition and resistance to Photobacterium damselae subsp piscicida. Aquaculture Research 43: 662-669.

20. Al-Dohail MA, Hashim R, Aliyu-Paiko M (2011) Evaluating the use of Lactobacillus acidophilus as a biocontrol agent against common pathogenic bacteria and the effects on the haematology parameters and histopathology in African catfish Clarias gariepinus juveniles. Aquacultre Research 42: 196-209.

21. Bhatnagar I, Kim SK (2010) Immense Essence of Excellence: Marine Microbia Bioactive Compounds. Marine Drugs 8: 2673-2701.

22. Gondry M, Sauguet L, Belin P, Thai R, Amouroux R, et al. (2009) Cyclodipeptide synthases are a family of tRNA-dependent peptide bond-forming enzymes. Natural Chemical Biology 5: 414-420

23. Fdhila F, Vázquez V, Sánchez JL, Riguera R (2003) DD-Diketopiperazines: Antibiotics Active against Vibrio anguillarum Isolated from Marine Bacteria Associated with Cultures of Pecten Maximus. J Nat Prod 66: 1299-1301.

24. Milne PJ, Kilian G (2010) The Properties, Formation, and Biological Activity of 2,5-Diketopiperazines. Comprehensive Natural Products II. Chemistry \& Biology 5: 657-698

25. Zheng CJ, Yoo JS, Lee TG, Cho HY, Kim YH, et al. (2005) Fatty acid synthesis is a target for antibacterial activity of unsaturated fatty acids. Federation of European Biochemical Societies 579: 5157-5162. 
Citation: Leyton Y, Riquelme C (2013) Oleic Acid and Diketopiperazines Produced by Marine Bacteria Reduce the Load of the Pathogen Vibrio parahaemolyticus in Argopecten purpuratus. J Aquac Res Development 4: 179 doi:10.4172/2155-9546.1000179

Page 5 of 5

26. Huang CB, George B, Ebersole JL (2010) Antimicrobial activity of n-6, n-7 and $\mathrm{n}-9$ fatty acids and their esters for oral microorganisms. Arch Oral Biol 55: 555560
27. Cordova JL, Astorga J, Silva W, Riquelme C (2002) Characterization by PCR of Vibrio parahaemolyticus isolates collected during the 1997-1998 Chilean outbreak. Biological Research 35: 433-440. 